\title{
Nonlinear approaches in testing PPP: Evidence from Southern African development community
}

\author{
Mulatu F. Zerihun ${ }^{\dagger}$ Marthinus C. Breitenbach ${ }^{*}$ Francis Kemegue $^{*}$
}

\section{Highlights}

- The BDS and the Fourier stationarity tests are employed.

- Both tests confirm the non-linear behaviour in the real exchange series.

- Furthermore, the result from the Fourier test provides evidence of an OCA in the SADC.

- The findings in this study will encourage integration initiatives in the region.

† Corresponding author: Research Associate, Department of Economics, University of Pretoria, South Africa.

Phone: +27 (012) 382 0557, EMail:zerihunmulatufekadu606@gmail.com //// Zerihunmulatufekadu606@tut.ac.za

* Marthinus C. Breitenbach. Telephone: +27 (012) 842 3437. EMail: martin.breitenbach@up.ac.za

Department of Economics, University of Pretoria, South Africa. Pretoria 0002, Republic South Africa.

${ }^{*}$ Research Associate, Department of Economics, University of Pretoria, South Africa. Pretoria 0002, South Africa, phone: +27 (012) 420 3461, E-Mail: fkemegue@ framingham.edu 


\section{Conflict of Interest}

The authors have no conflict of interest to disclose.

\section{Abstract}

In this paper two nonlinearity tests are employed: the nonparametric test developed by Brock, Dechert and Scheinkman - known as the BDS test and the Fourier stationarity test. The BDS non-linearity test detects whether the independent and identically distribute (iid) assumption of the time series used in the analysis holds true or not while the Fourier approximation mimics a wide variety of breaks and other types of nonlinearities. Both tests confirm the non-linear nature of real exchange series in SADC. The result from the Fourier stationary test further provides strong evidence of an OCA among the 11 SADC countries included in this study.

Key Words: Optimal Currency Area; Purchasing Power Parity; Real Exchange Rate; Fourier Stationary Test; BDS Test

JEL Classification: C22, C32, F15, F31

\section{INTRODUCTION}

The objective of the regional integration agenda in southern Africa is to create a fully integrated internationally competitive region to ensure economic growth and poverty reduction. The region faces a number of challenges achieving this goal but according to the African Development Bank (AfDB, 2011), the region is well positioned to take advantage of them. The success of the integration process depends on stable economies in terms of inflation rates, interest rates, exchange rates and levels of employment, among other factors (UNECA, 2010). Member states should consider regional integration as part of their broader strategic development objectives. In meeting these strategic objectives, it is important to understand the impact of regional economic integration on the economies concerned. It is even more important that SADC policy makers understand the unintended consequences of monetary integration. SADC has a monetary 
integration agenda and therefore much interest in studying optimum currency area (OCA) criteria in SADC.

To arrive at more conclusive results it is advisable to focus not only on PPP but also on the real interest rate parity (IRP). However, in this paper, we analyse only one of the criteria of modern optimal currency area (OCA) theory, namely purchasing power parity (PPP) since there is evidence that IRP holds among SADC countries (Aziakpono, et al., 2012).

According to OCA theory, if PPP holds, one of the criteria of OCA theory is met and there is potential that countries may form an OCA and therefore move toward full monetary integration. Literature on PPP in SADC is very limited. Usually PPP is studied by exploring the time series properties of real exchange rates. The vast majority of studies are based on linear tests for meanreversion in real exchange rates such as the Engle-Granger and Johansen cointegration tests. Arghyrou and Gregorious (2007), argue that real exchange rate time series is stationary and nonlinear, as is common with many macroeconomic variables in the literature. However, the implicit assumption of linearity of real exchange rates has made the majority of existing empirical literature on long-run PPP behaviour inconclusive and/or inconsistent.

Does the PPP hold for SADC member countries as an OCA criterion toward full monetary integration? To answer this question we make use of the BDS nonlinearity test to test for nonlinearity of the real exchange rate series and Fourier unit root tests to make inferences about the suitability of SADC member states to form a monetary union, based on whether or not there is PPP. To the best of our knowledge, this study is the first to utilize the BDS test and flexible Fourier stationary test to test for long-run PPP in SADC economies. The BDS test detects the independent and identically distributed (iid) assumption of the time series used in the analysis, 
while the Fourier approximation mimics a wide variety of breaks and other types of nonlinearities. The investigation of nonlinearities and asymmetries in macroeconomic behaviour constitutes an increasingly popular area of empirical research ( Holmes, 2001 and Su et al., 2014). A prior study in the SADC region (Mokoena, et al., 2009) using real exchange rates argued that non-linear approaches to exchange rate adjustments are likely to provide a firmer basis for inference and stronger support for PPP in the long term in the region. However, the authors haven't made any inference about monetary integration in the SADC region. These findings provide firm ground for our analysis and hence we test the hypothesis that PPP will hold for most of the member countries of SADC. The major contribution of this paper to the literature is the fact that we apply non-linear methods (BDS \& Fourier) to investigate PPP, and hence testing criteria of OCA, which have not been applied to this type of investigation before.

The remainder of this paper is organized as follows. Section 2 reviews the theoretical background of the study in brief; Section 3 presents the data and methodology; Section 4 presents the empirical results and discussions and the last section concludes the paper.

\section{THEORETICAL BACKGROUND IN BRIEF}

In this section we present a brief theoretical review on three interrelated theories, namely the exchange rate-, PPP-, and OCA theory as they relate to monetary integration. These areas of research have seen a revival following the experience of the European Monetary Union (EMU), which is perceived to have been beneficial to its members (Dellas and Tavlas, 2009). OCA theory, an approach for analysing monetary unions, dates back to 1961 with Mundell's (1961) seminal article setting out the theoretical foundations of the theory. Following Mundell's works, 
McKinnon (1963), Kenen (1969) and other economists made great contributions to refine the theory. Given the experience of the EMU, the degree of real convergence should be one of the criteria satisfied by prospective entrants prior to entry into the euro area (Buiter, 2008). The degree of real convergence also determines the choice of exchange rate regime. PPP of the real exchange rate, as a real convergence criterion for OCA, is supposed to hold among the countries aspiring to form a monetary union. Here it is important to highlight the fact that why exchange rate equilibrium and hence PPP is an OCA criterion. This follows from the fact that equilibrium exchange rate is defined as the real exchange rate that allows an economy to reach its internal and external equilibriums. Exchange rate misalignments constitute not only an indicator of competitiveness, but also a useful indicator of the viability of a monetary union (Coulibaly and Gnimassoun, 2013). Indeed, large differences in competitiveness between countries within a monetary union could lead to current account imbalances, as evidenced by the recent experience of the Euro area (Coudert et al., 2013). In the absence of PPP among member states, it would be difficult for the common central bank to set up common monetary and exchange rate policies, which in turn could challenge the stability of the union. Furthermore, as exchange rate misalignments are affected by many variables related to the OCA theory like; price differences and economic fundamentals such as terms of trade shocks, trade and fiscal policies, and productivity shocks; they can be viewed as an overall indicator of the viability of a monetary union compared to other OCA criteria. Moreover, Fielding (2005) argues the importance of the real exchange rate as well as that of the output and price shocks in analysing the costs and benefits of a monetary union. 
PPP is based on the law of one price and implies that exchange rates should equalize the national price levels of different countries in terms of a common currency (Taylor, 2003). According to PPP, any change in relative national price levels between two countries should lead to a corresponding adjustment in their bilateral nominal exchange rate. This suggests that variations in the real exchange rate represent deviations from PPP. Consequently, one avenue for investigating the empirical validity of PPP is to examine the characteristics of the real exchange rate. In particular, since PPP implies the mean reversion of real exchange rates or their tendency to eventually return to PPP-determined levels in response to any disturbance, whether real exchange rates are stationary or non-stationary, becomes an issue of central significance. Stationary real exchange rates imply mean reversion and thus provide empirical support for PPP, according to Taylor et al. (2001).

Regarding the time series dynamic properties of real exchange rates, there are two strands identified in the literature; namely, linear and nonlinear. Recent studies have focused on exploring the nonlinear behaviour of real exchange rates (Aksoy and Leon-Ledesma, 2007, McMillan, 2007 and Mokoena et al., 2009). The literature further identifies factors that lead to the nonlinear nature of real exchange rate series such as transaction costs in various markets and policy intervention or the actions of market agents in financial speculation and arbitrage behaviour (McMillan, 2007). 


\section{DATA AND METHODOLOGY}

\subsection{Data}

This study covers a sample of 11 SADC member countries. Four member states of SADC namely the DRC, Lesotho, Namibia and Zimbabwe are not included in this study because of incomplete data. Monthly data for the period January 1995 to August 2012 are used in this study. All data relating to consumer price indices (CPI) (based on 2005=100) and nominal exchange rates relative to the US dollar are from the IMF International Financial Statistics. Each of the consumer price index and nominal exchange rate series is transformed into natural logarithms before the econometric analysis. In logarithmic form, the real exchange rate $\left(y_{i, t}\right)$ is calculated as follows:

$$
y_{i, t}=s_{i, t}+p_{u s, t}^{*}-p_{i, t}
$$

where $y_{i, t}$ is the logarithm of the real exchange rate against the US dollar, $s_{i, t}$ is the logarithm of the nominal exchange rate against the US dollar, and $p_{u s, t}^{*}$ and $p_{i, t}$ respectively, are the logarithms of consumer price indices in the US and country ' $i$ '.

As shown in Table 1, Zambia has the highest mean real exchange rate followed by Madagascar and Tanzania, whereas Botswana has the lowest followed by Seychelles and South Africa. All the countries' exchange rates are symmetrically distributed around the mean since the measures of skewness for each country is close to zero. The Jarque-Bera test however, reveals that the (log) real exchange rate series of SADC countries are not normally distributed. This normality test is significant for all countries in the sample at a 1 percent level of significance, except for Madagascar which is significant at the 5 percent level. However, in this study the focus is not to 
Table 1: Descriptive Statistics and Normality Test of SADC (Log) Real Exchange Rate

\begin{tabular}{|l|l|l|l|l|l|l|l|l|l|}
\hline Country & $\begin{array}{l}\text { Country } \\
\text { Code }\end{array}$ & Mean & Median & Maximum & Minimum & $\begin{array}{l}\text { Std. } \\
\text { Dev. }\end{array}$ & Skewness & Kurtosis & $\begin{array}{l}\text { Jarque- } \\
\text { Bera }\end{array}$ \\
\hline Angola & AGO & 4.460 & 4.479 & 5.627 & 1.966 & 0.551 & -0.867 & 5.800 & $95.768 * * *$ \\
\hline Botswana & BWA & 1.714 & 1.696 & 2.129 & 1.493 & 0.143 & 0.743 & 2.945 & $19.527 * * *$ \\
\hline Madagascar & MDG & 7.438 & 7.453 & 7.894 & 7.171 & 0.152 & 0.114 & 2.155 & $6.767 * *$ \\
\hline Malawi & MWI & 4.629 & 4.680 & 5.107 & 4.083 & 0.215 & -0.910 & 3.432 & $30.886 * * *$ \\
\hline Mauritius & MUS & 3.300 & 3.335 & 3.492 & 3.093 & 0.111 & -0.262 & 1.833 & $14.453 * * *$ \\
\hline Mozambique & MOZ & 3.118 & 3.104 & 3.457 & 2.874 & 0.146 & 0.559 & 2.463 & $13.603 * * *$ \\
\hline South Africa & ZAF & 1.909 & 1.884 & 2.528 & 1.592 & 0.193 & 0.975 & 3.992 & $42.273 * * *$ \\
\hline Seychelles & SYC & 1.798 & 1.733 & 2.263 & 1.558 & 0.158 & 1.054 & 3.212 & $39.619 * * *$ \\
\hline Swaziland & SWZ & 1.949 & 1.911 & 2.580 & 1.581 & 0.207 & 0.832 & 3.416 & $25.979 * * *$ \\
\hline Tanzania & TZA & 6.911 & 6.937 & 7.161 & 6.635 & 0.118 & -0.470 & 2.462 & $10.357 * * *$ \\
\hline Zambia & ZMB & 8.476 & 8.601 & 9.066 & 7.904 & 0.316 & -0.284 & 1.481 & $23.240 * * *$ \\
\hline
\end{tabular}

Source: own computation from sample data (1995m1-2012m8)

Note: $* *$ and $* * *$ indicate significance at the $5 \%$ and $1 \%$ levels, respectively. 
examine nonlinearity versus non-normality in real exchange rate dynamics. As discussed in the next section we use the BDS test to make inferences about nonlinearity from the non-normality test. For the details on nonlinearity versus non-normality in real exchange rate dynamics see (Arghyrou \& Gregoriou, 2008).

\subsection{Methodology}

Many nonlinear models may be used to investigate the dynamic behaviour of real exchange rates. Exponential smooth transition autoregressive (ESTAR) models, threshold autoregressive (TAR) models, smooth transition autoregressive (STAR) models, and Markov switching models (MS) are the most widely used for this purpose. To prove the question posed empirically we first use the Brock et al.(1996) test (here after referred to as the BDS test) to test for non-linearity of the real exchange rate series. Thereafter we use the flexible Fourier stationarity test proposed by Becker et al.(2006) to confirm nonlinearity and test for PPP. Su et al. (2012) also employ the Fourier stationarity test for the analysis of real exchange rate dynamics in 20 selected African countries for the fact that such series are of low frequency and often exhibit structural breaks. In such cases, flexible Fourier tests are more suitable, according to Enders and Lee (2009 and 2012) and Pascalu (2010).

\subsubsection{BDS Nonlinearity Test}

The motivation for the BDS test goes with the 'independent and identically distributed' (iid) assumption in time series data. To detect this assumption non-parametric tests like BDS are more appropriate than parametric tests. It is generally believed that a non-parametric model provides a more robust approach to statistical inference because it is more likely to approximately capture 
the true underlying structure (Delegado \& Robinson, 1992; Yatchew, 1998; Epstein \& Scheider, 2003). Following Belaire \& Coutreras (2002), let $Y_{t}$ be a univariate real exchange rate series that is iid from some distribution. Also, define

$$
P_{A}=\operatorname{Pr}\left(\left|Y_{t}-Y_{s}\right|<\varepsilon\right)
$$

as the probability that two points are within a distance ' $\varepsilon$ ' of each other. Further we can define:

$$
\left.P_{B}=\operatorname{Pr}\left|Y_{t}-Y_{s}\right|<\varepsilon,\left|Y_{t-1}-Y_{s-1}\right|<\varepsilon\right)
$$

Equation 3 holds true as the probability of a history of the two observations being within $\varepsilon$ of each other. Under independence of $Y_{t}$, the two events contained in the event B are independent and therefore $P_{B}=P_{A}^{2}$. One can estimate $P_{A}$ and $P_{B}$ and also $P_{B}-P_{A}^{2}$, which has an expected value of zero under the null hypothesis. To estimate the probability that two $m$ length vectors are within $\varepsilon$, define:

$c_{m, n}(\varepsilon)=\frac{2}{(n-m+1)(n-m)} \sum_{s=m}^{n} \sum_{t=s+1}^{n} \prod_{j=0}^{m-1} I_{\varepsilon}\left(Y_{s-j}, Y_{t-j}\right)$

where

$I_{\varepsilon}\left(Y_{s-j}, Y_{t-j}\right)=\left\{\begin{array}{lc}1 & \text { if }\left|Y_{t-1}-Y_{s-1}\right|<\varepsilon \\ 0 & \text { otherwise }\end{array}\right.$

Here $\mathrm{n}$ is the sample size and $\mathrm{m}$ is the so-called embedding dimension. Under the null of iid,

$$
E\left(C_{m, n}(\varepsilon)\right)=\left(E\left(C_{1, n}(\varepsilon)\right)\right)^{n}
$$

Brock et al. (1996) show that, given an embedding dimension, m, and a value of the radius, ${ }^{\varepsilon}$, the BDS statistic is given as:

$$
w_{m, n}(\varepsilon)=\sqrt{n-m+1} \frac{c_{m, n}(\varepsilon)-c_{1, n-m+1}^{m}(\varepsilon)}{\sigma_{m, n}(\varepsilon)}
$$

It is asymptotically distributed as $\mathrm{N}(0,1)$. This formula uses the square root of the consistent estimator 
Table 2: The BDS test results for the monthly exchange rate time series (fraction of pairs)

\begin{tabular}{|c|c|c|c|c|c|c|c|c|c|c|c|}
\hline \multirow[b]{3}{*}{$\mathrm{m}$} & \multicolumn{11}{|c|}{$\begin{array}{l}\text { BDS Statistics of SADC Real Exchange Rates - country codes as local currency/USD } \\
\mathrm{H}_{0}=\text { independent and identically distributed (iid) } \text {, is rejected in all cases }\end{array}$} \\
\hline & \multicolumn{11}{|c|}{ Country Codes } \\
\hline & ANG & BWA & MDG & MWI & MUS & MOZ & ZAF & SYC & SWZ & TZA & ZMB \\
\hline 2 & 0.169 & 0.1796 & 0.1650 & 0.1779 & 0.181 & 0.175 & 0.176 & 0.181 & 0.175 & 0.174 & 0.181 \\
\hline 3 & 0.2857 & 0.3015 & 0.2745 & 0.2957 & 0.303 & 0.290 & 0.295 & 0.302 & 0.294 & 0.291 & 0.304 \\
\hline 4 & 0.3610 & 0.3827 & 0.3446 & 0.3711 & 0.385 & 0.364 & 0.373 & 0.381 & 0.375 & 0.366 & 0.387 \\
\hline 5 & 0.4114 & 0.4342 & 0.3869 & 0.4177 & 0.437 & 0.408 & 0.423 & 0.431 & 0.425 & 0.411 & 0.440 \\
\hline 6 & 0.443 & 0.465 & 0.4103 & 0.4444 & 0.470 & 0.432 & 0.452 & 0.461 & 0.456 & 0.435 & 0.475 \\
\hline $\mathrm{c}_{1}, \mathrm{n}(\varepsilon)$ & 0.7701 & 0.208 & 0.243 & 0.298 & 0.181 & 0.217 & 0.262 & 0.240 & 0.293 & 0.179 & 0.562 \\
\hline $\mathrm{k}_{1}(\varepsilon)$ & 3824810 & 3821906 & 3831102 & 3823116 & 3817066 & 3814646 & 3830134 & 3825536 & 3821180 & 3818034 & 3806902 \\
\hline \multirow{2}{*}{ V-Statistic } & 0.7033 & 0.7027 & 0.7045 & 0.7030 & 0.7019 & 0.701 & 0.7042 & 0.7034 & 0.702 & 0.702 & 0.700 \\
\hline & \multicolumn{11}{|c|}{$\mathrm{P} * * *<0.001, \mathrm{~m}=$ embedding dimension, included observations $(\mathrm{n}): 2332$} \\
\hline
\end{tabular}

Source: own computation from sample data (1995m1-2012m8) 
$\sigma_{m, n}^{2}(\varepsilon)=4\left[k^{m}+2 \sum_{j=1}^{m-1} k^{m-j} c^{2 j}+(m-1)^{2} c^{2 m}-m^{2} k c^{2 m-2}\right]$

where

$$
\begin{aligned}
& \mathrm{c}=\mathrm{c}_{1, \mathrm{n}}(\varepsilon) \\
& \mathrm{k}=\mathrm{k}_{\mathrm{n}}(\varepsilon)=\frac{6}{n(n-1)(n-2)} \sum_{t=1}^{n} \sum_{s=t+1}^{n} \sum_{r=s+1}^{n} h_{\varepsilon}\left(Y_{t}, Y_{s}, Y_{r}\right) \\
& \mathrm{h}_{\varepsilon}(i, j, k)=\frac{1}{3}\left[I_{\varepsilon}(i, j) I_{\varepsilon}(j, k)+I_{\varepsilon}(i, k) I_{\varepsilon}(k, j)+I_{\varepsilon}(j, i) I_{\varepsilon}(i, k)\right]
\end{aligned}
$$

The consistent estimators $\mathrm{c}_{1, \mathrm{n}}(\varepsilon)$ and $\mathrm{k}_{\mathrm{n}}(\varepsilon)$ are in the class of $\mathrm{U}$-statistics and, as is pointed out by Kanzler (1999) they are the most efficient estimators of $c$ and $k$, respectively (See BDS test result in Table 2).

\subsubsection{Stationary test with a Fourier function}

\section{Motivations for Fourier Unit Root Test}

There have been methodological problems testing the validity of the PPP hypothesis and hence to obtain robust results about the existence of PPP, which would satisfy one of the criteria of OCA theory and support monetary union. First, one has to know the exact number and location of the breaks in the series. These are not usually known and therefore need to be estimated. This in turn introduces an undesirable pre-selection bias (see Maddala \& Kim, 1998). Second, current available tests account only for one to two breaks. Third, the use of dummies suggests sharp and sudden changes in the trend or level. However, for low frequency data it is more likely that structural changes take the form of large swings which cannot be captured well using only dummies. Breaks should therefore be approximated as smooth and gradual processes (see Leybourne et al., 1998). These arguments motivate the use of a recently developed set of unit root and stationarity tests that avoid this problem. Both Becker et al. (2006) and Enders and Lee 
(2009) develop tests that model any structural break of an unknown form as a smooth process via Flexible Fourier transformations. Several authors, including Becker et al. (2006), Enders and Lee (2009), and Pascalau (2010), show that a Fourier approximation can often capture the behaviour of an unknown function even if the function itself is not periodic.

Marcela et al. (2003) and Narayan (2006) provide evidence that, when structural breaks are included for individual countries, the real exchange rate is stationary, implying support for PPP. Chang et al. (2012) applied a flexible Fourier stationary test to test the validity of long-run PPP in a sample of East Asian countries over the period January 1986 to October 2009. The empirical results from this study indicate that PPP does not hold for most of the East Asian countries, with the exception of Indonesia and Japan.

This procedure allows us to study the non-linear mean-reverting behaviour of PPP without having to specify the kind of nonlinear adjustment process. Enders and Lee (2004, 2009) develop their unit root test using the Lagrange Multiplier (LM) principle. As indicated by Pascalau (2010), the LM has increased power over the Dickey-Fuller (DF) approach. Following Enders and Lee (2004, 2009), we consider the following Data Generating Process (DGP):

$$
\begin{gathered}
\mathrm{y}_{\mathrm{t}}=\alpha_{0}+\theta_{t}+\gamma_{1} \sin (2 \pi k t / T)+\gamma_{2} \cos (2 \pi k t / T)+\varepsilon_{t} \\
\varepsilon_{t}=\beta \varepsilon_{t-1}+u_{t} \\
\Delta \mathrm{y}_{\mathrm{t}}=\delta_{0}+\delta_{1} \sin (2 \pi k t / T)+\delta_{2} \cos (2 \pi k t / T)+v_{t}
\end{gathered}
$$


Table 3: Stationary Test with a Nonlinear Fourier Unit Root Test

\begin{tabular}{|l|c|c|c|c|c|}
\hline \multicolumn{1}{c|}{$\begin{array}{c}\text { Country } \\
\text { Code }\end{array}$} & $\begin{array}{c}\text { Obs. } \\
\text { (T) }\end{array}$ & SSRs & $\hat{k}$ & $F_{\mu}(\hat{k})$ & $\tau_{\mu}(\hat{k})$ \\
\hline AGO & 200 & 1.295 & 1 & $220.18^{* * *}$ & $-7.033^{* * *}$ \\
\hline BWA & 203 & 0.146 & 1 & $446.14^{* * *}$ & $-2.731^{* * *}$ \\
\hline MDG & 210 & 0.227 & 1 & $418.91^{* * *}$ & $-3.841^{* * *}$ \\
\hline MWI & 199 & 0.311 & 1 & $360.60^{* * *}$ & $-2.731^{* * *}$ \\
\hline MUS & 204 & 0.052 & 1 & $554.05^{* * *}$ & $-1.298^{* * *}$ \\
\hline MOZ & 199 & 0.131 & 1 & $446.58^{* * *}$ & $-3.529 * * *$ \\
\hline ZAF & 203 & 0.248 & 1 & $392.53^{* * *}$ & $-3.004^{* * *}$ \\
\hline SYC & 200 & 0.195 & 1 & $409.52^{* * * *}$ & $-2.461^{* * *}$ \\
\hline SWZ & 203 & 0.311 & 1 & $369.82^{* * * *}$ & $-2.653^{* * *}$ \\
\hline TZA & 199 & 0.058 & 1 & $525.94^{* * * *}$ & $-3.085^{* * *}$ \\
\hline ZMB & 203 & 0.349 & 1 & $357.99 * * *$ & $-0.410^{* * *}$ \\
\hline
\end{tabular}

Source: own computation from sample data (1995m1-2012m8)

Where $k(1 \leq k \leq 5)$ is the number of frequencies of the Fourier function, ' $\mathrm{t}$ ' is a trend term, ' $\mathrm{T}$ ' is the number of usable observations in the regression analysis and the term $\left[\delta_{1} \sin (2 \pi k t / T)+\delta_{2} \cos (2 \pi k t / T)\right]$ captures structural change in the real exchange rate series $\left\{y_{t}\right\}$.

There is non-linearity and unknown breaks if the hypothesis $\delta_{1}=\delta_{2}=0$ is rejected using the Fstatistics $F(k)$ of Table 3 in Enders and Lee (2004). The ' $k$ ' in $F(k)$ is the $k_{\min }$ obtained by regressing equation (10), which gives the minimum residual sum of squares (RSS) for different frequencies. The rejection of the above hypothesis is indicative of the presence of structural breaks. If $\theta=0$ (using the $\tau_{D F}$ statistics from Table 3 in Enders and Lee 2004), there is a unit root. However, if $\theta$ is significantly different from zero, we reject the unit root taking into account nonlinearity and possible structural breaks. Therefore the series $\left\{y_{t}\right\}$ is stationary. That is the 
series exhibits stochastic convergence (Nyong, 2013). Further details on the methodological aspects of this paper can be found in Enders and Lee (2004, 2009). The Fourier unit root test result is presented in Table 3.

\section{RESULTS AND DISCUSSION}

Univariate unit root tests show that the real exchange rate data of the SADC economies included in this study have a unit root and every series is non-stationary implying that linear specification in this case would be inappropriate (Mokoena et al., 2009). Our results on non-stationarity of the series are not reported but are available on request. As discussed in section 2, real exchange rate series of 11 SADC countries were used in this study with monthly data from 1995 to 2012. Since the real exchange rate is found stationary by using the unit root test with structural break(s), the effects of shocks such as real and monetary shocks that cause deviations around a mean value or deterministic trend are only temporary. Thus, PPP is valid in the long run in SADC region.

Table 2 provides the BDS statistics for all eleven exchange rate series of SADC countries included in the study. The results strongly suggest that the real exchange rate series of all the SADC countries included in this study reject the iid null hypothesis at the 1 percent level significance implying the non-normality and non-linearity of the series by inference. The Fourier unit root test results are reported in Table 3 with the time paths of SADC countries included in this study. Given the findings from the BDS test, the Fourier approximations appear reasonable to use in detecting unit roots in SADC countries. 
The third column in Table 3 shows the sum of square of residuals (SSRs). The F-test for SSRs for all the SADC countries included in the study is significant at the 1 percent level. Given the result in column four a single frequency works best for all of the SADC countries in the study. As shown in the fifth column of Table 3 the statistical values are all significant at a 1 percent level of significance. This condition implies that both the sine and cosine terms in equation (12) in the methodology section should be included in the estimated model. Thus, the hypothesis $\delta_{1}=\delta_{2}=0$ is rejected using the F-statistics, F (k), of Table 3 in Enders and Lee (2004). The last column in Table 3 reports the results of unit root tests with a nonlinear function based on the estimated frequencies. All the T-statistic values for the 11 SADC member countries are significant at a 1 percent significance level. The Fourier function provides evidence favouring the validity of long-run PPP for the SADC member countries included in this study. The logarithm of real exchange rate is nonlinear stationary, implying that deviations from the real exchange rate are mean reverting towards the PPP equilibrium. These findings are in line with the findings by Chi-Wei Su et al. (2013) and Zerihun et al. (2014) that strongly support PPP equilibrium for African countries analysed in both studies respectively. These authors further suggest that trade barriers as well as interventions in the exchange markets could be behind this nonlinear behaviour.

\section{CONCLUSION}

The goal of the regional integration agenda in southern Africa is to create a fully integrated internationally competitive region to ensure economic growth and poverty reduction. However, countries in the region need to conform to OCA criteria before forming a monetary union. Given the long run dynamics of real exchange rates for the 11 member countries of SADC using the 
Fourier estimation method, our findings come out in support of the region being an OCA based on the PPP criteria. As this study suggests policy makers in these 11 SADC countries could use PPP to predict a common exchange rate which would determine whether a currency is over- or under-valued and experiencing differences between domestic and foreign inflation rates.

This study provides valuable findings for policy makers which evaluate the readiness of SADC economies to complete the process of monetary integration in the region. The findings in this study imply that the region is potentially an OCA, which may proceed with the envisaged monetary integration in the region and move toward monetary union and eventually a single currency. The findings in this study may avert pessimistic views of integration initiatives in the African continent in general and the SADC region in particular. However, policy makers ought to use the findings as insightful results rather than complete evidence given the relatively small sample period used in the study compared with studies in OECD countries. This study further finds that SADC real exchange rate series exhibit nonlinear behaviour. Exploring the explanations behind nonlinear behaviour of SADC real exchange rate series requires further research. Such studies are critical not only in respect of their contribution to the literature on OCA theory in SADC, but also to provide more substantial empirical evidence to policymakers.

\section{Acknowledgments}

We would like to acknowledge the Editor-in-chief and anonymous referees for their valuable comments on the earlier draft of the manuscript that led to significant improvements in the current version. This paper benefited from the valuable comments suggested by the participants at 18th Annual African Econometrics Society (AES) Conference on Econometric Analysis and Policy Challenges in Africa 24-26 July 2013 La Palm Royale Hotel, Accra, Ghana. We thank the African Econometrics Society, African Development Bank, Departments of Economics at the University of Ghana and at the University of Pretoria for financial support to attend the conference. We are also appreciative to Junsoo Lee for providing WinRATS Pro 8.1 program codes used in this study. A special note of appreciation goes to Economic Research Southern Africa (ERSA), both for valuable recommendations and financial support in respect of this paper - an earlier version of which was published in the ERSA Working Paper Series. 


\section{REFERENCES}

African Development Bank 2011. Southern African regional integration strategy paper.2011-2015, BP 323 -1002 TUNIS Belvédère (Tunisia).

Aksoy Y, Leon-Ledesma M.A. 2007. Non-Linearities and Unit Roots in G7 Macroeconomic Variables. The B.E. Journal of Macroeconomics, Vol. 8, No. 1, Article 5. Available at SSRN:

http://ssrn.com/abstract=1017076 or http://dx.doi.org/10.2139/ssrn.1017076. Accessed on: 12-03-2014

Arghyrou G, Gregorious A. 2007. Testing for purchasing power parity correcting for non-normality using the wild bootstrap. Economic Letters, 95:285-290.

Arghyrou G, Gregorious A. 2008. Non-linearity versus non-normality in real exchange rate dynamics. Economic Letters, 100:200-203.

Becker, R., Enders, W, Lee, J. 2006. A stationary test in the presence of an unknown number of smooth breaks. Journal of Time Series Analysis, 27:381-409.

Belaire-Franch J, Contreras-Bayarri D . 2002. The BDS test: a practitioner's guide. DT 02-01, University of Valencia. [Online] Accessed from: http: //centros.uv.es/ web/ departamentos/D10/data/investigacion/PDF132.pdf. Accessed on: 06 March 2013.

Brock W, Davis D, José S, Blake LeBaron. 1996. A test for independence based on the correlation dimension. Econometric Reviews, vol. 15-3, pp. 197-235.

Buiter W. 2008. Economic, Political, and Institutional Prerequisites for Monetary Union among the Members of the Gulf Cooperation Council. CEPR Discussion Paper Series, no. 6639.

Burgess R.2009. The South African development community's macroeconomic convergence programme: initial performance, IMF staff position Note, SPN/09/14.

Chang T, Tang P, Chiu L.K. 2009. Purchasing power parity in East Asian countries: flexible Fourier stationary test. Asian Journal of Business and Management Sciences, Vol: 1(5).

Chang T, Chiu L.K. 2012. Flexible Fourier stationary test in unemployment for G-7 countries. Economics and Finance Review Vol. 1(2). Available online at http://wwww.businessjournalz.org/efr. Accessed on: 12-04-2012.

Chi-Wei S, Hsu-Ling C, Meng-Nan Z.2012. Flexible Fourier stationary test in purchasing power parity for African countries. Applied Economics, 44(25). Available online at http://dx.doi.org/10.1080/00036846.2011.570729 Accessed on: 12-04-2012.

Dellas H, Tavlas G. 2009. An optimum-currency-area odyssey. Working paper number 102, Economic Research Department, Bank of Greece, Athens.

Delgado M.A, Robinson P.M. 1992. Nonparametric and Semi parametric methods for economic research. Working paper 92-19, Department of economics, University of Carlos III, Madrid, Spain.

Enders W, Lee J. 2004. Testing for a unit root with a nonlinear Fourier function. Working paper, Department of Economics, Finance \& Legal Studies, University of Alabama, Tuscaloosa, AL, USA. 
Enders W, Lee J. 2006. Testing for a unit root with a nonlinear Fourier function mimeo. University of Alabama, Tuscaloosa, AL.

Enders W, Lee, J. 2009. The Flexible Fourier Form and Testing for Unit Roots: An Example of the Term Structure of Interest Rates, WORKING Paper, Department of Economics, Finance and Legal Studies, University of Alabama, Tuscaloosa, AL,USA.

Enders W, Lee, J. 2012. A unit root test using a Fourier series to approximate smooth breaks. Oxford Bulletin of Economics and Statistics, 74, 4 (2012) 0305-9049 doi: 10.1111/j.1468-0084.2011.00662.x.

Epstein L.G, Schneider M. 2003. IID: independently and indistinguishably distributed. Journal of Economic Theory, 113, pp. 32-50

Frankel J.A, Rose A.K. 1998.The endogeneity of optimum currency area. Economic Journal, 108, 10091025.

Holmes M.J. 2001. New evidence on real exchange rate stationarity and purchasing power parity in less developed countries. Journal of Macroeconomics, 23, 601-614.

IMF. 2007. IMF exchange rate policy advice: findings and recommendations. IMF Independent Evaluation Office. Available at: http://www.ieo-imf.org/eval/complete/eval_05172007.html Accessed on: $12-12-12$.

Kenen P.B. 1969. "Theory of optimum currency areas" In: Mundel R. and Swoboda, A. Monetary Problems in the International Economy, Chicago: University of Chicago Press.

Kanzler L. 1999. Very Fast and Correctly Sized Estimation of the BDS Statistic. [Online] Available at SSRN: http://ssrn.com/abstract=151669 or http://dx.doi.org/10.2139/ssrn.151669.

Kumo W. L. 2011. Growth and macroeconomic convergence in Southern Africa, Series $\mathrm{N}^{\circ} 130$, African Development Bank, Tunis, Tunisia.

Lee J, Strazicich, M. C. 2003. Minimum Lagrange multiplier unit root test with two structural breaks, The Review of Economics and Statistics, 85, 1082-9.

Leybourne S, Newbold P, Vougas D. 1998. Unit roots and smooth transitions. Journal of Time Series Analysis, 19:83-97.

Maddala G, Kim, I. 1998. Unit Roots, Cointegration and Structural Change, Cambridge University Press, Cambridge.

Maddala G, Wu S. 1999. A comparative study of unit root tests with panel data a new simple test. Oxford Bulletin of Economics and Statistics, Special Issue, pp.631-652.

Marcela S, Gadea M.D, Serrano, J.M. 2003. PPP and structural breaks: the peseta sterling rate, 50 years of floating regime. Journal of International Money and Finance, 22, p. 613-627.

McKinnon, R. 1963. Optimum currency areas. American Economic Review, 53, September. 
McMillan, D.G. 2007. The confusing time-series behaviour of real exchange rates: Are asymmetries important? School of Management ,University of St Andrews, The Gateway, North Haugh, St Andrews, KY16 9SS, UK.

Mokoena T M, Gupta R, Reneé Van Eyden. 2009. Testing for PPP using SADC real exchange rates. South African Journal of Economics, 77:3.

Mundell, R. 1961. A theory of optimum currency areas. American Economic Review 51, September.

Narayan, P.K. 2006. Are bilateral real exchange rates stationary? Evidence from Lagrange multiplier unit root tests for India. Applied Economics, 38, 63-70.

Nyong M.O, Omobitan O.A. 2013. Nonlinear income convergence and structural breaks: further empirical evidence. International Journal of Economics and Finance, Vol. 5(4).

Pascalau, R. 2010. Unit root tests with smooth breaks: an application to the Nelson-Plosser data set, Applied Economics Letters, 17, 565-70.

Su Chi-Wei, Chang Hsu-Ling, Zhu, Meng-Nan. 2013. Flexible Fourier stationary test in purchasing power parity of African countries, Applied Economics, 44:25, 3255-3262.

Taylor M.P. 2003. Purchasing power parity. Review of International Economics, 11: 436-52.

Taylor M.P, Peel D.A, Sarno, L. 2001. Nonlinear mean-reversion in real exchange rates: Towards a solution to the purchasing power parity puzzles. International Economic Review, 42: 1015-1042.

Taylor, A. M, Taylor, M. P. 2004.The purchasing power parity debate. Journal of Economic Perspectives, 18: $135-58$.

UNECA. 2010. Assessing regional integration in Africa IV: enhancing intra-African trade. Addis Ababa, Ethiopia.

Yatchew A. 1998. Nonparametric Regression Techniques in Economics. Journal of Economic Literature, 36(2): 669-721. Accessed from: http://www.jstor.org/stable/2565120. Accessed on: 19/12/2013

Zerihun M.F, Breitenbach M.C, Kemegue F. 2014. Greek wedding in SADC? Testing for structural symmetry toward SADC monetary integration. The African Finance Journal, Vol. 16(2). 